\title{
Faktor-faktor yang Mempengaruhi Kepatuhan Wajib Pajak dalam Membayar Pajak Kendaraan Bermotor
}

\author{
Cokorda Istri Putra Nirajenani ${ }^{1}$ \\ Ni Kt. Lely Aryani $\mathbf{M}^{2}$ \\ ${ }^{1}$ Fakultas Ekonomi dan Bisnis Universitas Udayana (Unud), Bali, Indonesia \\ email: coknira64@yahoo.com/ Telp: +6285737795768 \\ ${ }^{2}$ Fakultas Ekonomi dan Bisnis Universitas Udayana (Unud), Bali, Indonesia
}

\begin{abstract}
ABSTRAK
Penelitian ini bertujuan untuk mendapatkan bukti empiris mengenai pengaruh kesadaran wajib pajak, kualitas pelayanan, pemahaman peraturan perpajakan, sanksi perpajakan dan sosialisasi perpajakan terhadap kepatuhan wajib pajak dalam membayar pajak kendaraan bermotor di kantor SAMSAT Gianyar. Teori yang digunakan dalam penelitian ini adalah Theory of Planned Behavior. Jumlah sampel yang diteliti sebanyak 100 wajib pajak kendaraan bermotor. Metode penentuan sampel menggunakan accidental sampling, yaitu mengambil responden sebagai sampel secara kebetulan. Pengumpulan data dilakukan melalui penyebaran kuesioner. Teknik analisis yang digunakan adalah analisis regresi linear berganda. Berdasarkan hasil analisis disimpulkan bahwa kesadaran wajib pajak, kualitas pelayanan, pemahaman peraturan perpajakan, sanksi perpajakan dan sosialisasi perpajakan berpengaruh positif terhadap kepatuhan wajib pajak dalam membayar pajak kendaraan bermotor di kantor SAMSAT Gianyar.

Kata Kunci: Kesadaran wajib pajak, kualitas pelayanan, pemahaman peraturan perpajakan, sanksi perpajkan dan sosialisasi perpajakan.
\end{abstract}

\begin{abstract}
This study aims to obtain empirical evidence on the influence of taxpayer awareness, service quality, understanding tax laws, taxation sanctions and tax dissemination on taxpayer compliance in paying motor vehicle tax at SAMSAT Gianyar office. The theory used in this research is Theory of Planned Behavior. The number of samples examined were 100 motor vehicle taxpayers. The method of determining the sample using accidental sampling, which takes the respondent as a sample by chance. Data collection was done through questionnaires. The analysis technique used is multiple linear regression analysis. Based on the analysis, it can be concluded that the awareness of taxpayers, the quality of service, the understanding of taxation regulations, taxation sanctions and tax socialization have a positive effect on taxpayer compliance in paying motor vehicle tax at SAMSAT Gianyar office.

Keywords: Taxpayer awareness, service quality, understanding of tax laws, tax sanctions and tax dissemination.
\end{abstract}


Cokorda Istri Putra Nirajenani dan Ni Kt. Lely Aryani M. Pengaruh...

\section{PENDAHULUAN}

Pajak merupakan sumber penerimaan yang sangat besar dan penting bagi negara. Pajak adalah sumber pendanaan dalam melaksanakan tanggung jawab negara untuk mengatasi masalah sosial, meningkatkan kesejahteraan dan kemakmuran serta kontak sosial antara warga negara denga pemerintah (Dharma, 2014). Berdasarkan kewenangannya, pajak dibedakan menjadi pajak pusat dan pajak daerah. Sumber pembiayaan pembangunan daerah dapat digali dari Pendapatan Asli Daerah (AA. Chintya dan Lely, 2013).

Memiliki Pendapatan Asli Daerah yang maksimal merupakan keinginan setiap daerah. Sumber Pendapatan Asli Daerah (PAD) yang banyak berkontribusi pada setiap Daerah adalah Pajak Daerah yang wajib dipenuhi dan dipaksakan bagi setiap orang baik pribadi, kelompok maupun badan/lembaga yang berdasarkan Undang-undang. Pendapatan daerah yang bersumber dari PAD diperoleh melalui Pajak Daerah, Retribusi daerah, hasil pengelolaan kekayaan daerah yang dipisahkan.

Pajak Daerah merupakan salah satu sumber penerimaan daerah yang terutang oleh pribadi atau badan yang bersifat memaksa berdasarkan undangundang dengan tidak mendapatkan imbalan secara langsung dan digunakan untuk keperluan daerah. Hal tersebut sesuai dangan Undang-undang No. 28 Tahun 2009 tentang Pajak Daerah dan Retribusi Daerah: "Pajak daerah digunakan untuk keperluan Daerah, selanjutnya disebut pajak, adalah kontribusi wajib kepada daerah yang terutang oleh orang pribadi atau badan yang bersifat memaksa berdasarkan Undang-Undang, dengan tidak mendapatkan imbalan secara langsung 
dan digunakan untuk keperluan Daerah bagi sebesar-besarnya kemakmuran rakyat". Salah satu jenis penerimaan pajak daerah diantaranya di dapat melalui pajak kendaraan bermotor (PKB). Pemungutan pajak kendaraan bermotor merupakan jenis pemungutan yang sudah lama dilakukan oleh pemerintah. Pajak kendaraan bermotor adalah pajak atas kepemilikan dan/atau penguasaan kendaraan bermotor. Perkembangan kendaraan bermotor di daerah Gianyar saat ini sangat pesat. Hal tersebut dapat dilihat pada Tabel 1 berikut.

Tabel 1.

Jumlah Kendaraan Bermotor yang Tercatat di Kabupaten Gianyar Tahun 2013-2016

\begin{tabular}{|c|c|c|c|c|c|}
\hline \multirow{2}{*}{ No } & \multirow{2}{*}{ Jenis Kendaraan } & \multicolumn{4}{|c|}{ Tahun } \\
\hline & & 2013 & 2014 & 2015 & 2016 \\
\hline 1 & Sedan & 23,539 & 25,923 & 1,465 & 1,379 \\
\hline 2 & Jeep & 1,090 & 1,462 & 3,396 & 3,421 \\
\hline 3 & Minibus/Bus & 6,726 & 7,209 & 22,900 & 24,716 \\
\hline 4 & Pick Up & 1,205 & 1,208 & 6,808 & 6,907 \\
\hline 5 & Truck & 4,415 & 4,859 & 5,345 & 5,595 \\
\hline \multirow[t]{2}{*}{6} & Sepeda Motor & 183,371 & 190,702 & 194,985 & 194,426 \\
\hline & mlah Unit & 220,346 & 231,363 & 234,899 & 236,444 \\
\hline
\end{tabular}

Banyaknya kendaraan bermotor di Kabupaten Gianyar seharusnya pemerintah daerah bisa mendapatkan penerimaan pajak yang lebih dari sektor ini, realisasi penerimaan pajak kendaraan bermotor meningkat namun jumlah tunggakan dan denda masih meningkat setiap tahunnya. Hal ini dapat dilihat dari jumlah tunggakan dan denda yang disajikan pada Tabel 2 berikut. 
Tabel 2.

Realisasi Penerimaan Pajak Kendaraan Bermotor, Tunggakan dan Denda di Kantor Bersama SAMSAT Gianyar Tahun 2014-2016

\begin{tabular}{cccc}
\hline Tahun & Realisasi Penerimaan $(\mathbf{R p )}$ & $\begin{array}{c}\text { Tunggakan } \\
(\mathbf{R p})\end{array}$ & $\begin{array}{c}\text { Denda } \\
(\mathbf{R p})\end{array}$ \\
\hline $\mathbf{2 0 1 3}$ & 64.225 .380 .600 & 2.195 .871 .800 & 2.044 .021 .600 \\
$\mathbf{2 0 1 4}$ & 71.874 .142 .200 & 3.412 .149 .400 & 3.270 .626 .100 \\
$\mathbf{2 0 1 5}$ & 70.284 .820 .050 & 3.294 .242 .000 & 3.768 .924 .200 \\
$\mathbf{2 0 1 6}$ & 73.223 .884 .000 & 5.480 .605 .147 & 3.343 .382 .057 \\
\hline Sumber $:$ Kantor Bersama SAMSAT Gianyar, 2017 & &
\end{tabular}

Berdasarkan Tabel 2 dapat dilihat bahwa jumlah tunggakan dan denda setiap tahunnya terus meningkat, Pemerintah harus bisa memaksimalkan kembali pendapatan dari pajak kendaraan bermotor. Hal ini mengindikasikan terdapat salah satu kendala yaitu pada kepatuhan wajib pajak dalam memenuhi kewajibannya.

Peran pajak sebagai penerimaan dalam negeri menjadi sangat dominan, namun masih belum optimal jika dilihat dari banyaknya wajib pajak yang belum menjadi wajib pajak patuh. Chau dan Leung (2009:39) berpendapat bahwa faktor yang mempengaruhi penerimaan pajak suatu negara diantaranya adalah tingkat kepatuhan wajib pajak masyarakat di negara tersebut. Masalah kepatuhan wajib pajak adalah masalah yang penting di seluruh dunia, baik itu di negara maju maupun di negara berkembang, karena jika wajib pajak tidak patuh maka akan menimbulkan keinginan untuk melakukan tindakan penghindaran, pengelakan dan pelalaian pajak. Saat ini bila pajak tidak dipatuhi dan dipenuhi pembayarannya oleh wajib pajak maka pemerintah tidak dapat berjalan dengan baik (Hammer et al., 2005).

Menurut Yadnyana dan Sudiksa (2011) kepatuhan pajak adalah suatu sikap terhadap fungsi pajak, berupa konstelasi dari komponen kognitif, efektif, dan 
konatif yang berinteraksi dalam memahami, merasakan dan berperilaku terhadap makna dan fungsi pajak. Kepatuhan Wajib Pajak dapat dipengaruhi oleh dua jenis faktor yaitu faktor internal dan faktor eksternal. Faktor internal merupakan faktor yang berasal dari diri Wajib Pajak sendiri dan berhubungan dengan karakteristik individu yang menjadi pemicu dalam menjalankan kewajiban perpajakannya. Berbeda dengan faktor internal, faktor eksternal adalah faktor yang berasal dari luar diri Wajib Pajak, seperti situasi dan lingkungan di sekitar Wajib Pajak (Fuadi \& Yenni, 2013). Kepatuhan yang meningkat akan mendukung upaya pemerintah untuk meningkatkan kesejahteraan masyarakat (Gerald, 2009). Grasmick dan Scott 1982 (dalam Davis et at., 2003) menyebutkan bahwa seseorang yang mengetahui wajib pajak yang tidak patuh, maka seseorang tersebut kemungkinan akan memiliki kecenderungan mengikuti ketidakpatuhan tersebut.

Kesadaran wajib pajak dapat dilihat dari kesungguhan dan keinginan wajib pajak untuk memenuhi kewajiban pajaknya yang ditunjukkan dalam pemahaman wajib pajak terhadap fungsi pajak dan kesungguhan wajib pajak dalam membayar pajak. Semakin tinggi tingkat kesadaran Wajib Pajak, maka pemahaman dan pelaksanaan kewajiban perpajakan semakin baik sehingga dapat meningkatkan kepatuhan (Sugi dan Lely, 2017). Kesadaran wajib pajak masih dikatakan rendah jika dilihat dari jumlah tunggakan dan denda Pajak Kendaraan Bermotor (PKB) di Kantor Samsat Gianyar. Kesadaran wajib pajak mengenai perpajakan sangatlah diperlukan guna meningkatkan kepatuhan wajib pajak (Cindy dan Yeni, 2013). James dan Nobes (1997) mengatakan kesadaran masyarakat yang tinggi akan mendorong semakin banyak masyarakat memenuhi kewajibannya untuk 
mendaftarkan diri sebagai wajib pajak, melaporkan dan membayar pajaknya dengan benar sebagai wujud tanggung jawab dalam berbangsa dan bernegara.

Meningkatkan kepatuhan wajib pajak diperlukan juga pemahaman pengetahuan perpajakan oleh wajib pajak itu sendiri. Susilawati dan Budiartha (2013), menyatakan bahwa pemahaman mengenai arti dan manfaat pajak dapat meningkatkan kesadaran dari wajib pajak. Tanpa adanya pengetahuan tentang pajak dan manfaatnya tidak mungkin masyarakat secara sukarela membayar pajaknya. Pemahaman akan peraturan perpajakan merupakan suatu hal yang penting guna meningkatkan kesadaran wajib pajak. Jika wajib pajak tidak mengetahui dan paham tentang pajak serta manfaat dari pajak itu sendiri, maka tidak mungkin orang tersebut akan secara ikhlas membayar pajaknya. Pemahaman wajib pajak terhadap peraturan perpajakan merupakan cara wajib pajak dalam memenuhi peraturan perpajakan yang telah ada (Hardiningsih, 2011). Pengetahuan pajak yang rendah dapat menyebabkan ketidakpercayaan dan sikap negatif terhadap pajak, sedangkan pengetahuan pajak yang baik berkorelasi dengan sikap positif terhadap pajak (Niemirowski et al., 2003).

Faktor lain yang dapat mempengaruhi tingkat kepatuhan wajib pajak adalah kualitas pelayanan. Parasuraman, et al., (1998) mendefinisikan kualitas pelayanan sebagai kemampuan organisasi untuk memenuhi atau melebihi harapan pelanggan. Penelitian Rajif (2012) menyatakan bahwa memberikan pelayanan yang baik dapat meningkatkan kepatuhan dari wajib pajak. Kualitas pelayanan yang baik merupakan salah satu upaya dalam meningkatkan kepatuhan wajib pajak. Kualitas pelayanan petugas yang baik diharapkan dapat meningkatan 
kepuasan wajib pajak sehingga meningkatkan kepatuhan dalam memenuhi kewajiban perpajakannya. Pelayanan yang berkualitas merupakan kemampuan suatu instansi yang dapat memberikan kepuasan pada pelanggan dan tetap dalam batas memenuhi standar pelayanan yang dapat dipertanggung jawabkan (Gilbert et al., 2004). Pelayanan petugas yang baik akan memberikan kenyamanan bagi wajib pajak. Salah satu upaya yang dapat dilakukan guna meningkatkan kualitas pelayanan yaitu dengan menyediakan sarana-prasarana maupun sistem informasi terutama dalam pembentukan perilaku petugas yang siap melayani masyarakat selaku wajib pajak.

Selain upaya meningkatkan kualitas pelayanan kepada wajib pajak, terdapat sanksi yang dapat diterima wajib pajak apabila melanggar ketentuan yang berlaku menurut Undang-undang. Sanksi perpajakan merupakan sebuah jaminan bahwa ketentuan peraturan perundang-undangan perpajakan akan dipatuhi, dengan kata lain sanksi perpajakan merupakan alat pencegah agar wajib pajak tidak melanggar norma perpajakan (Mardiasmo, 2011). Sanksi pajak memiliki peran penting guna memberikan pelajaran bagi pelanggar pajak agar tidak meremehkan peraturan perpajakan. Sanksi yang dikenakan dalam jumlah yang tinggi akan mendorong wajib pajak untuk lebih patuh (Wahyu, 2008). Banyak wajib pajak yang membayar 5 tahun sekaligus atau tidak sama sekali. Oleh karena tidak diiringi dengan sanksi perpajakan menyebabkan masyarakat menganggap remeh kewajibannya (Susilawati dan Budiarta, 2013). Sanksi akan dikenakan lebih berat apabila pelanggaran yang dilakukan wajib pajak semakin besar. Wajib Pajak akan memenuhi kewajiban 
perpajakannya apabila memandang bahwa sanksi perpajakan akan lebih banyak merugikannya (Nugroho, 2006).

Sosialisasi perpajakan merupakan suatu upaya Direktorat Jenderal Pajak untuk memberikan pengertian, informasi, dan pembinaan kepada masyarakat pada umumnya dan wajib pajak pada khususnya mengenai segala sesuatu yang berhubungan dengan perpajakan dan perundang-undangan. Sulistianingrum (2009) mengatakan bahwa sosialisasi dapat dilakukan melalui media komunikasi, baik media cetak seperti surat kabar, majalah maupun media audio visual seperti radio atau televisi. Penelitian Kurniawan (2006) menyatakan bahwa sosialisasi perpajakan berpengaruh secara signifikan terhadap kepatuhan Wajib Pajak. Maka dari itu, melalui sosialisasi perpajakan WP akan mengerti dan mengetahui pentingnya peran pajak untuk pembangunan suatu Negara, serta pentingnya pajak bagi kemajuan suatu bangsa.

Berdasarkan penelitian sebelumnya, masih terdapat ketidakkonsistenan dari hasil penelitian terdahulu. Hasil penelitian yang dilakukan Yulayca (2013) menunjukan bahwa pengetahuan pajak berpengaruh negatif dan tidak signifikan pada kepatuhan wajib pajak di KPP Surakarta. Namun, penelitian dari Susilawati (2013) menyatakan pengetahuan pajak berpengaruh positif pada kepatuhan wajib pajak. Hasil yang berlawanan ini, maka peneliti tertarik untuk meneliti kembali hubungan pengetahuan pajak terhadap kepatuhan wajib pajak. Berdasarkan pokok permasalahan tersebut, maka yang menjadi tujuan dari penelitian ini adalah untuk mendapatkan bukti empiris pengaruh kesadaran wajib pajak, kualitas pelayanan, 
pemahaman peraturan perpajakan, sanksi perpajakan, dan sosialisasi perpajakan terhadap kepatuhan wajib pajak dalam membayar pajak kendaraan bermotor.

Penilaian positif wajib pajak terhadap pelaksanaan fungsi negara oleh pemerintah akan menggerakkan masyarakat untuk mematuhi kewajibannya untuk membayar pajak, maka dari itu kesadaran Wajib Pajak mengenai perpajakan sangatlah diperlukan guna meningkatkan kepatuhan Wajib Pajak. Semakin tinggi tingkat kesadaran wajib pajak maka pemahaman dan pelaksanaan kewajiban perpajakan semakin baik sehingga dapat meningkatkan kepatuhan (Dewinta dan Syafruddin, 2012).

Theory of Planned Behavior sangat relevan untuk menjelaskan perilaku wajib pajak dalam memenuhi kewajiban perpajakannya. Sebelum individu melakukan sesuatu, individu tersebut akan memiliki keyakinan mengenai hasil yang akan diperoleh dari perilakunya tersebut. Hal tersebut berkaitan dengan kesadaran wajib pajak. Wajib pajak yang sadar pajak, akan memiliki keyakinan mengenai pentingnya membayar pajak untuk membantu menyelenggarakan pembangunan negara (behavioral beliefs). Penelitian Yudha (2011) dan Putri (2012) membuktikan bahwa kesadaran wajib pajak berpengaruh positif terhadap kepatuhan wajib pajak dalam membayar pajak. Hasil tersebut menunjukkan bahwa wajib pajak yang memiliki kesadaran wajib pajak akan lenih patuh dalam menunaikan kewajiban pajak kendaraan bermotornya. Berdasarkan hasil penelitian sebelumnya maka hipotesis yang diajukan dalam penelitian ini adalah.

$\mathrm{H}_{1}$ : Kesadaran wajib pajak berpengaruh positif terhadap kepatuhan wajib pajak dalam membayar Pajak Kendaraan Bermotor di Kantor SAMSAT Gianyar. 
Cokorda Istri Putra Nirajenani dan Ni Kt. Lely Aryani M. Pengaruh...

Ukuran keberhasilan penyelenggaraan pelayanan ditentukan oleh tingkat kepuasan penerima pelayanan. Kepuasan penerima pelayanan dicapai apabila penerima pelayanan memperoleh kualitas pelayanan sesuai dengan yang dibutuhkan dan diharapkan secara terus-menerus. Penyelenggaraan pelayanan yang dapat memberikan kepuasan optimal bagi wajib pajak berhubungan dengan kualitas pelayanan yang diberikan. Pelayanan kepada wajib pajak sebagai pelanggan dikatakan bermutu bila memenuhi atau melebihi harapan wajib pajak, atau semakin kecil kesenjangannya antara pemenuhan janji dengan harapan pelanggan adalah semakin mendekati ukuran bermutu.

Theory of Planned Behavior terdapat faktor normative belief yang berkaitan dengan kualitas pelayanan dimana ketika akan melakukan sesuatu, individu akan memiliki keyakinan tentang harapan normatif dari orang lain dan motivasi untuk memenuhi harapan tersebut (normative beliefs). Dengan adanya pelayanan yang baik dari petugas pajak, sistem perpajakan yang efisien dan efektif, serta penyuluhan-penyuluhan pajak yang memberikan motivasi kepada wajib pajak agar taat pajak, akan membuat wajib pajak memiliki keyakinan atau memilih perilaku taat pajak. Penelitian yang dilakukan oleh Andriana (2011) dan Adi (2012) menunjukkan bahwa kualitas pelayanan berpengaruh positif terhadap kepatuhan wajib pajak dalam membayar pajak. Berdasarkan hasil penelitian sebelumnya maka hipotesis yang diajukan dalam penelitian ini adalah.

$\mathrm{H}_{2}$ : Kualitas pelayanan pajak berpengaruh positif terhadap kepatuhan wajib pajak kendaraan bermotor di Kantor SAMSAT Gianyar. 
Pemahaman akan peraturan perpajakan akan meningkatkan kepatuhan sesorang dalam memenuhi kewajiban perpajakannya. Masalah tingkat pemahaman akan praturan perpajakan dari wajib pajak dirasa perlu untuk dibahas karena pengetahuan perpajakan adalah salah satu faktor potensial bagi pemerintah untuk meningkatkan kepatuhan wajib pajak dalam memenuhi kewajiban perpajakannya. Apabila wajib pajak memahami peraturan perpajakan yang dimiliki maka akan mempengaruhi patuh tidaknya wajib pajak itu sendiri dalam melaksanakan kewajiban perpajakannya. Penelitian Pratiwi (2015) dan Winoto (2008) menunjukkan bahwa pengetahuan pajak berpengaruh signifikan terhadap kepatuhan wajib pajak. Berdasarkan hasil penelitian sebelumnya maka hipotesis yang diajukan dalam penelitian ini adalah.

$\mathrm{H}_{3}$ : Pemahaman peraturan perpajakan berpengaruh positif terhadap kepatuhan wajib pajak kendaraan bermotor di Kantor SAMSAT Gianyar.

Sanksi perpajakan merupakan pemberian sanksi bagi wajib pajak yang tidak memenuhi kewajibannya sesuai dengan ketentuan peraturan perundang-undangan perpajakan yang berlaku. Terdapat undang-undang yang mengatur tentang ketentuan umum dan tata cara perpajakan. Agar peraturan perpajakan dipatuhi, maka harus ada sanksi perpajakan bagi para pelanggarnya. Menurut Mardiasmo (2013:47) menyatakan bahwa Sanksi perpajakan merupakan jaminan bahwa ketentuan perundang-undangan perpajakan (norma perpajakan) akan dituruti/ditaati/dipatuhi. atau bisa dengan kata lain sanksi perpajakan merupakan alat pencegahan (preventif) agar wajib pajak tidak melanggar norma perpajakan.

Sanksi pajak terkait dengan control beliefs. Sanksi pajak dibuat adalah untuk mendukung agar wajib pajak mematuhi peraturan perpajakan. Kepatuhan wajib pajak 
akan ditentukan berdasarkan persepsi wajib pajak tentang seberapa kuat sanksi pajak mampu mendukung perilaku wajib pajak untuk taat pajak. Penelitian yang dilakukan oleh Agus (2006) membuktikan bahwa sanksi perpajakan berpengaruh positif terhadap kepatuhan wajib pajak. Berdasarkan hasil penelitian sebelumnya maka hipotesis yang diajukan dalam penelitian ini adalah.

$\mathrm{H}_{4}$ : Sanksi perpajakan berpengaruh positif terhadap kepatuhan wajib pajak dalam membayar Pajak Kendararaan Bermotor di Kantor SAMSAT Gianyar.

Sosialisasi Perpajakan yang baik diharapkan dapat meningkatkan kepatuhan wajib pajak. Pentingnya sosialisasi memberikan pengertian kepada masyarakat dalam membayar pajak, dengan adanya sosialisasi perpajakan masyarakat menjadi mengerti dan paham mengenai manfaat membayar pajak (Winerungan,2013). Herryanto dan Toly (2013) mengatakan kurangnya pengetahuan dan wawasan pajak karena rendahnya sosialisasi perpajakan akan menyebabkan wajib pajak tidak memahami bagaimana cara melaksanakan kewajiban perpajakan dan pada akhirnya tidak melaksanakan kewajibannya tersebut, hal tersebut akan berdampak pada penerimaan pajak negara. Penelitian yang dilakukan oleh Dharma (2014), menyimpulkan bahwa sosialisasi perpajakan berpengaruh signifikan terhadap Kepatuhan Wajib Pajak PKB dan BBNKB. Berdasarkan hal tersebut, maka dirumuskan hipotesis sebagai berikut.

$\mathrm{H}_{5}$ : Sosialisasi perpajakan berpengaruh positif terhadap kepatuhan wajib pajak dalam membayar Pajak Kendararaan Bermotor di Kantor SAMSAT Gianyar 


\section{METODE PENELITIAN}

Penelitian ini dilakukan menggunakan penelitian asosiatif dengan pendekatan kuantitatif. Penelitian asosiatif merupakan penelitian yang bertujuan untuk mengetahui hubungan antara dua variabel atau lebih. Sedangkan penelitian kuantitatif yaitu penelitian dengan memperoleh data yang berbentuk angka atau data kualitatif yang diangkakan (Sugiyono, 2016:14). Hubungan antar variabel dapat digambarkan dengan kerangka pemikiran seperti pada Gambar 1 berikut:

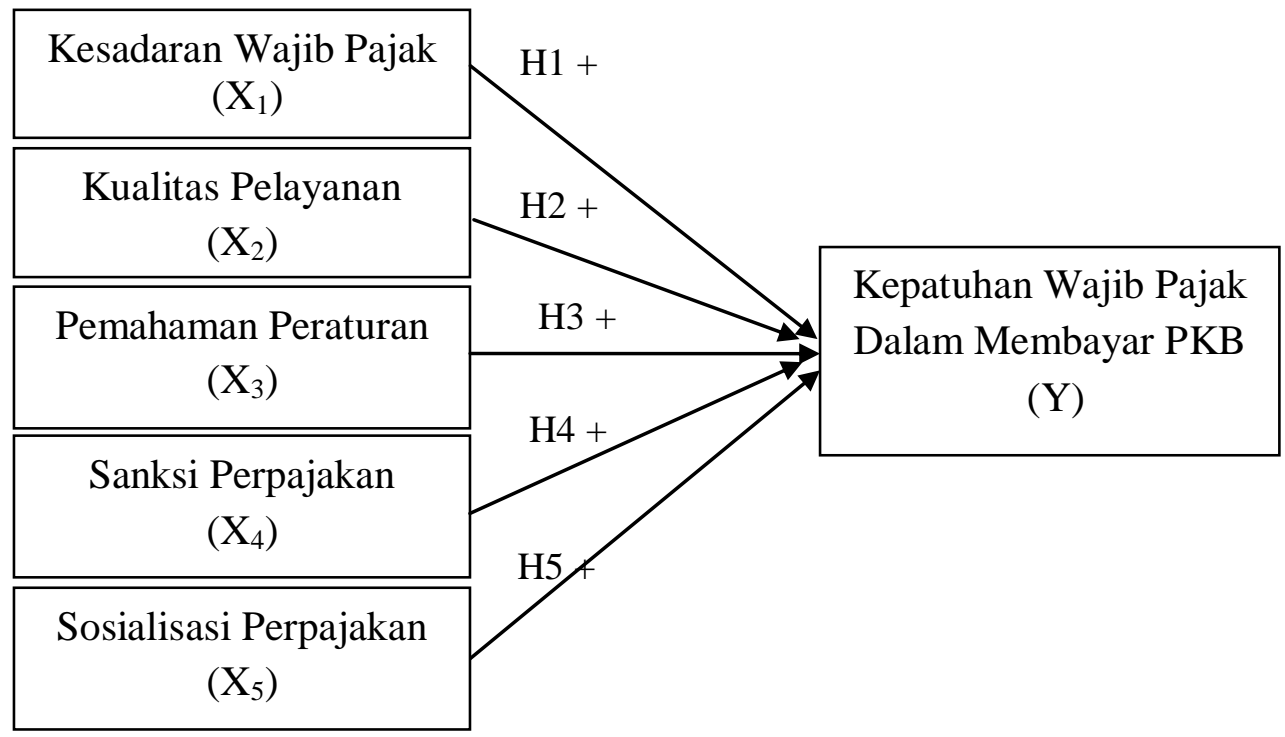

\section{Gambar 1. Kerangka Konsep Penelitian}

Penelitian ini dilakukan pada kantor SAMSAT Kabupaten Gianyar yang beralamat di Jl. Raya Samplangan, Gianyar. Alasan memilih lokasi ini karena peningkatan jumlah tunggakan dan denda terus meningkat setiap tahunnya maka dari itu perlu diteliti kembali apakah peningkatan tersebut berbanding lurus dengan jumlah penerimaan pajak kendaraan bermotor. Objek yang diteliti pada penelitian ini adalah kepatuhan wajib pajak dalam membayar pajak kendaraan bermotor di kantor SAMSAT Kabupaten Gianyar. 
Penelitian ini menggunakan kepatuhan wajib pajak sebagai variabel terikat. Kepatuhan wajib pajak diukur dengan 4 indikator yang digunakan oleh Susilawati (2013), yaitu peraturan pajak kendaraan bermotor harus ditaati oleh seluruh wajib pajak, mengisi formulir pajak dengan lengkap dan jelas, wajib pajak membayar pajak kendaraan bermotor dalam jumlah yang sesuai dengan yang terdapat pada Surat Tanda Nomor Kendaraan (STNK), dan membayar pajak yang terutang tepat pada waktunya.

Variabel bebas dalam penelitian ini adalah kesadaran wajib pajak, kualitas pelayanan, pemahaman peraturan perpajakan, sanksi perpajakan dan sosialisasi perpajakan. Untuk mengukur variabel bebas dalam penelitian ini menggunakan instrumen yang dikembangkan oleh penelitian Susilawati (2013). Indikator yang digunakan untuk mengukur kesadaran membayar pajak antara lain 1) Pajak merupakan bentuk partisipasi dalam menunjang pembangunan daerah, 2) Penundaan pembayaran pajak dan penurangan beban pajak sangat merugikan daerah, dan 3) PKB ditetapkan dengan Undang-undang dan dapat dipaksakan. Indikator yang dapat digunakan untuk mengukur kualitas jasa pelayanan dalam penelitian ini terdiri dari bukti langsung (tangible), kehandalan (reliability), daya tanggap (responsiveness), jaminan (assurance), dan empati (empathy).

Variabel pemahaman peraturan perpajakan dalam penelitian ini diukur dengan 3 indikator yang dikembangkan oleh Januarta (2011), yaitu 1) Wajib mengetahui setiap kali ada perubahan peraturan perpajakan yang berhubungan dengan pajak kendaraan bermotor, 2) Wajib pajak mengetahui cara membayar 
pajak kendaraan bermotor dengan benar, 3) Wajib pajak membayar pajak kendaraan bermotor dalam jumlah yang sesuai dengan peraturan.

Variabel sanksi perpajakan dalam penelitian ini diukur dengan instrumen pernyataan yang dikembangkan oleh Yadnyana (2009) antara lain : 1) Sanksi administrasi yang dikenakan bagi pelanggar aturan pajak sangat ringan, 2) Sanksi pidana yang dikenakan bagi pelanggar aturan pajak cukup berat, 3) Pengenaan sanksi yang cukup berat merupakan salah satu sarana untuk mendidik wajib pajak, dan 4) Sanksi pajak yang harus dikenakan kepada pelanggan tanpa toleransi. Variabel sosialisasi perpajakan pada penelitian ini diukur dengan instrumen pernyataan yang terdiri dari 5 item pernyataan yang dikembangkan oleh Pani (2014), yaitu 1) Kegiatan penyuluhan yang diadakan oleh kantor SAMSAT mengenai $\mathrm{PKB}, 2$ ) Penguasaan materi dari petugas dalam memberikan penjelasan dan penyuluhan tentang PKB, dan 3) Anda memperoleh informasi yang lengkap tentang PKB melalui internet.

Populasi yang dimaksud dalam penelitian ini adalah seluruh wajib pajak kendaraan bermotor yang terdaftar pada Kantor SAMSAT Gianyar. Penelitian ini menggunakan metode accidental sampling. Accidental sampling adalah mengambil responden sebagai sampel secara kebetulan, yaitu siapa yang secara kebetulan bertemu dengan peneliti dapat digunakan sebagai sampel bila orang yang kebetulan ditemui cocok sebagai sumber data (Sugiyono, 2016:77). Kriteria responden yang menjadi sampel dalam penelitian ini adalah seluruh wajib pajak kendaraan bermotor yang terdaftar di Kantor SAMSAT Gianyar dan pemilik 
Cokorda Istri Putra Nirajenani dan Ni Kt. Lely Aryani M. Pengaruh...

kendaraan plat hitam yang merupakan milik pribadi wajib pajak kendaraan bermotor.

Besarnya ukuran sampel dihitung dengan menggunakan rumus Slovin, sehingga sampel yang digunakan dalam penelitian ini sebanyak 99,95 yang dibulatkan menjadi 100 (seratus) wajib pajak kendaraan bermotor milik pribadi di Kantor Bersama SAMSAT Gianyar. Teknik analisis data yang digunakan untuk memecahkan permasalahan yang terdapat dalam penelitian ini adalah Multiple Linier Regression (MLR) dengan menggunakan program SPSS (Statistical Product and Service Solution). Tahap analisis yang dilakukan adalah uji asumsi klasik yang terdiri dari uji normalitas, multikolinearitas, uji heteroskedastisitas, dan uji autokorelasi serta pengujian hipotesis secara statistik. Analisis regresi linear berganda (multiple linear regression) digunakan untuk menguji hipotesis yang ada yaitu untuk melihat pengaruh variabel kesadaran wajib pajak, kualitas pelayanan, pengetahuan perpajakan dan sanksi perpajakan terhadap kepatuhan wajib pajak dalam membayar pajak kendaraan bermotor, maka ditentukanlah bentuk model persamaan analisis regresi linear berganda sebagai berikut.

$$
Y=\alpha+\beta_{1} X_{1}+\beta_{2} X_{2}+\beta_{3} X_{3}+\beta_{4} X_{4}+\beta_{5} X_{5} \varepsilon_{1}
$$

Keterangan:

$$
\begin{aligned}
& Y=\text { kepatuhan wajib pajak } \\
& \alpha=\text { konstanta } \\
& \beta_{1} \ldots \beta_{4}=\text { koefisien regresi } \\
& X_{1}=\text { kesadaran wajib pajak } \\
& X_{2}=\text { kualitas pelayanan } \\
& X_{3}=\text { pengetahuan perpajakan } \\
& X_{4}=\text { sanksi perpajakan } \\
& X_{5}=\text { sosialisasi perpajakan } \\
& \varepsilon_{1}=\text { variabel pengganggu }
\end{aligned}
$$




\section{HASIL DAN PEMBAHASAN}

Karakteristik responden dalam penelitian ini digambarkan dengan jenis kelamin, umur, dan tingkat pendidikan responden. Karakteristik responden berdasarkan jenis kelamin dibagi 2 kategori. Kedua kategori tersebut dapat dilihat pada Tabel 3 berikut.

Tabel 3.

Karakteristik Responden menurut Jenis Kelamin

\begin{tabular}{cccc}
\hline Karakteristik & Klasifikasi & $\begin{array}{c}\text { Jumlah } \\
\text { (Orang) }\end{array}$ & $\begin{array}{c}\text { Persentase } \\
(\boldsymbol{\%})\end{array}$ \\
\hline \multirow{2}{*}{ Jenis Kelamin } & Laki-laki & 70 & 70 \\
& Perempuan & 30 & 30 \\
& Total & 100 & 100 \\
Umur & $20-25$ Tahun & 5 & 5 \\
& $26-30$ Tahun & 30 & 30 \\
Tingkat & 30 Tahun & 65 & 65 \\
Pendidikan & Total & 100 & 100 \\
& SMA & 20 & 20 \\
& D3 & 30 & 30 \\
& Sarjana & 50 & 50 \\
\hline
\end{tabular}

Sumber: Data Diolah, 2017

Pada Tabel 3, dapat dinyatakan bahwa sebagian besar responden adalah laki-laki dengan jumlah sebanyak 70 orang atau 70 persen dan sisanya adalah responden perempuan yaitu sebanyak 30 orang atau 30 persen. Data juga menunjukkan sebagian besar responden WP di Kabupaten Gianyar sebagian besar berumur $>30$ tahun, sebanyak 65 orang (65 persen), dan terendah pada kelompok umur 20-25 Tahun sebanyak 5 orang (5 persen). Apabila ditinjau berdasarkan tingkat pendidikan, maka dapat dinyatakan bahwa dari karakteristik tingkat pendidikan responden terbagi menjadi 3 kategori, tertinggi adalah tingkat pendidikan sarjana sebanyak 50 orang (50 persen), dan terendah adalah tingkat pendidikan SMA sebesar 20 orang (20 persen). 
Cokorda Istri Putra Nirajenani dan Ni Kt. Lely Aryani M. Pengaruh...

Pengujian instrumen penelitian menggunakan uji validitas dan uji reliabilitas dengan menggunakan bantuan program Statitical Package of Sosial Science (SPSS) 17.0. Uji validitas merupakan pengujian instrumen penelitian sebagai suatu derajat ketepatan alat ukur penelitian tentang inti atau arti sebenarnya yang diukur. Tinggi rendahnya validitas menunjukkan sejauh mana data yang terkumpul tidak menyimpang dari gambaran tentang variabel yang dimaksud. Suatu kuesioner dikatakan valid jika tiap butir pernyataan mampu mengungkapkan sesuatu yang akan diukur oleh kuesioner. Pengujian validitas tiap butir menggunakan analisis item yaitu, mengkorelasikan skor tiap butir atau faktor dengan skor total yang merupakan jumlah tiap skor butir. Syarat minimum suatu kuisioner untuk memenuhi validitas adalah jika korelasi antara butir dengan skor total tersebut positif dan nilainya lebih besar dari 0,30. Hasil uji validitas menunjukkan bahwa instrumen-instrumen pada setiap variabel dalam penelitian ini memiliki nilai korelasi hitung diatas 0,30 sehingga dapat disimpulkan bahwa, seluruh butir dalam instrumen penelitian ini dikatakan valid atau dapat dinyatakan layak digunakan sebagai alat ukur.

Reliabilitas adalah derajat ketepatan, ketelitian atau keakuratan yang ditunjukkan oleh instrument pengukuran dimana pengujiannya dapat dilakukan secara internal, yaitu pengujian dengan menganalisis konsistensi butir-butir yang ada. Adapun hasil dari uij reliabilitas dapat ditunjukkan pada Tabel 4 berikut. 
Tabel 4.

Hasil Uji Reliabilitas

\begin{tabular}{clcc}
\hline No. & \multicolumn{1}{c}{ Variabel } & Cronbach's Alpha & Keterangan \\
\hline 1 & Kesadaran WP & 0,922 & Reliabel \\
2 & Kualitas pelayanan & 0,986 & Reliabel \\
3 & Pemahaman peraturan & 0,965 & Reliabel \\
4 & Sanksi perpajakan & 0,983 & Reliabel \\
5 & Sosialisasi perpajakan & 0,854 & Reliabel \\
6 & Kepatuhan WP & 0,906 & Reliabel \\
\hline
\end{tabular}

Sumber : Data Diolah, 2017

Berdasarkan Tabel 4, nilai Cronbach's Alpha untuk setiap variabel lebih besar dari 0,6. Jadi, dapat dinyatakan bahwa seluruh variabel telah memenuhi syarat reliabilitas atau dapat dikatakan reliabel sehingga, dapat digunakan untuk melakukan penelitian.

Statistik deskriptif dalam penelitian ini disajikan untuk memberikan informasi mengenai karakteristik variabel-variabel penelitian, antara lain minimum, maksimum, mean, dan standar deviasi. Pengukuran rata-rata (mean) merupakan cara yang paling umum digunakan untuk mengukur nilai sentral dari suatu distribusi data. Sedangkan, standar deviasi merupakan perbedaan nilai data yang diteliti dengan nilai rata-ratanya.

Tabel 5.

Hasil Statistik Deskriptif

\begin{tabular}{lrrrrr}
\hline & N & \multicolumn{1}{c}{ Minimum } & Maximum & \multicolumn{1}{c}{ Mean } & Std. Deviation \\
\hline X1 & 100 & 7,00 & 11,00 & 8,9300 & 1,10330 \\
X2 & 100 & 11,00 & 20,00 & 14,9700 & 2,67595 \\
X3 & 100 & 3,00 & 11,00 & 8,5800 & 1,74761 \\
X4 & 100 & 8,00 & 14,00 & 10,5400 & 1,52037 \\
X5 & 100 & 6,00 & 12,00 & 8,4100 & 1,28782 \\
Y & 100 & 12,00 & 16,00 & 14,2300 & 1,12685 \\
\hline Valid N (listwise) & 100 & & & & \\
\hline Sumber :
\end{tabular}

Sumber : Data Diolah, 2017

Berdasarkan Tabel 5 dapat dilihat nilai minimum untuk kesadaran wajib pajak $\left(\mathrm{X}_{1}\right)$ adalah 7 dan nilai maksimumnya adalah 11. Mean untuk kesadaran 
wajib pajak adalah 8,93 , hal ini berarti rata-rata nilai kesadaran wajib pajak sebesar 8,93 . Standar deviasinya 1,10. Nilai minimum untuk variabel kualitas pelayanan $\left(\mathrm{X}_{2}\right)$ adalah 11 dan nilai maksimumnya adalah 20. Mean untuk kualitas pelayanan adalah 14,9 , hal ini berarti rata-rata nilai kualitas pelayanan sebesar 14,97. Standar deviasinya 2,67 .

Nilai minimum untuk variabel pemahaman peraturan $\left(\mathrm{X}_{3}\right)$ adalah 3 dan nilai maksimumnya adalah 11. Mean untuk pemahaman peraturan adalah 8,58 , hal ini berarti rata-rata nilai pemahaman peraturan sebesar 8,58. Standar deviasinya 1,74. Nilai minimum untuk variabel sanksi perpajakan $\left(\mathrm{X}_{4}\right)$ adalah 8 dan nilai maksimumnya adalah 14. Mean untuk kualitas pelayanan adalah 10,54 , hal ini berarti rata-rata nilai sanksi perpajakan sebesar 10,54. Standar deviasinya 1,52.

Nilai minimum untuk variabel sosialisasi perpajakan $\left(\mathrm{X}_{5}\right)$ adalah 6 dan nilai maksimumnya adalah 12. Mean untuk sosialisasi perpajakan adalah 6, hal ini berarti rata-rata nilai sosialisasi perpajakan sebesar 8,41. Standar deviasinya 1,28. Nilai minimum untuk variabel kepatuhan wajib pajak (Y) adalah 12 dan nilai maksimumnya adalah 16. Mean untuk kepatuhan wajib pajak adalah 14,23, hal ini berarti rata-rata nilai kepatuhan wajib pajak sebesar 14,9723. Standar deviasinya sebesar 1,12 .

Uji normalitas bertujuan untuk menguji apakah suatu data berdistribusi normal atau tidak. Penentuan normal atau tidaknya distribusi data dapat dilakukan pengujian dengan menggunakan statistik Kolmogorov-Smirnov. Hasil uji Kolomogorov Smirnov ditunjukkan pada Tabel 6 berikut. 
Tabel 6.

Hasil Uji Normalitas

\begin{tabular}{|c|c|c|}
\hline & & $\begin{array}{r}\text { Unstandardized } \\
\text { Residual }\end{array}$ \\
\hline $\mathrm{N}$ & & 100 \\
\hline \multirow[t]{2}{*}{ Normal Parameters ${ }^{\mathrm{a}, \mathrm{b}}$} & Mean & .0000000 \\
\hline & Std. Deviation & .55969277 \\
\hline \multirow[t]{3}{*}{ Most Extreme Differences } & Absolute & .119 \\
\hline & Positive & .069 \\
\hline & Negative & -.119 \\
\hline Kolmogorov-Smirnov Z & & 1.188 \\
\hline Asymp. Sig. (2-tailed) & & .119 \\
\hline
\end{tabular}

Hasil uji menunjukkan bahwa nilai Asymp. Sig. 0,119. Oleh karena nilai Asymp. Sig. lebih besar dari alpha 5 persen maka, dapat dinyatakan bahwa model uji telah memenuhi syarat normalitas data.

Uji multikolinearitas bertujuan untuk membuktikan atau menguji ada atau tidaknya hubungan yang linier (multikolinearitas) antara variabel bebas (independent) satu dengan variabel bebas yang lain. Adapun hasil dari uji multikolinieritas dapat ditunjukkan pada Tabel 7 berikut.

Tabel 7.

Hasil Uji Multikolinearitas

\begin{tabular}{llcr}
\hline Model & & \multicolumn{2}{c}{ Collinearity Statistics } \\
\cline { 3 - 4 } & & Tolerance & VIF \\
\hline 1 & (Constant) & .605 & 1.652 \\
& Kesadaran Wajib Pajak (X1) & .596 & 1.677 \\
& Kualitas Pelayanan (X2) & .665 & 1.505 \\
& Pemahaman Peraturan (X3) & .760 & 1.315 \\
& Sanksi Perpajakan (X4) & .710 & 1.409 \\
& Sosialisasi Perpajakan (X5) & & \\
& &
\end{tabular}

Sumber : Data Diolah, 2017

Berdasarkan Tabel 7 dapat ditunjukkan bahwa, nilai tolerance untuk kedua variabel bebas lebih besar dari 0,1 sedangkan nilai VIF kurang dari 10. Jadi dapat dinyatakan bahwa, model uji tidak terdeteksi kasus multikolinearitas atau dapat dikatakan tidak ada multikolinearitas. 
Uji heteroskedastisitas dilakukan untuk mengetahui bahwa pada model regresi terjadi ketidaksamaan varian. Untuk mendeteksi ada atau tidaknya heterokedastisitas digunakan model glejser. Model ini dilakukan dengan meregresikan nilai absolute ei dengan variabel bebas. Adapun hasil dari uji heterokedastisitas ini dapat ditunjukkan pada Tabel 8 berikut.

Tabel 8.

Hasil Uji Heteroskedastisitas

\begin{tabular}{llrrrrr}
\hline Model & & \multicolumn{2}{c}{$\begin{array}{c}\text { Unstandardized } \\
\text { Coefficients }\end{array}$} & $\begin{array}{c}\text { Standardized } \\
\text { Coefficients }\end{array}$ & & \\
\cline { 2 - 5 } & & \multicolumn{1}{c}{ B } & Std. Error & Beta & \multicolumn{1}{c}{ t } & Sig. \\
\hline 1 & (Constant) & 1.321 & .688 & & 1.919 & .058 \\
& Kesadaran Wajib Pajak (X1) & -.048 & .039 & -.157 & -1.237 & .219 \\
& Kualitas Pelayanan (X2) & -.024 & .016 & -.188 & -1.464 & .146 \\
& Pemahaman Peraturan (X3) & .036 & .023 & .185 & 1.526 & .130 \\
& Sanksi Perpajakan (X4) & -.066 & .065 & -.296 & -1.008 & .281 \\
& Sosialisasi Perpajakan (X5) & .034 & .031 & .128 & 1.094 & .277 \\
\hline Sumber : Data diolah, 2017 & & & & &
\end{tabular}

Berdasarkan Tabel 8 dapat ditunjukkan bahwa, kelima variabel bebas tidak berpengaruh signifikan terhadap nilai variabel terikatnya (absolute ei). Hal ini ditunjukkan dari nilai signifikansi yang lebih besar dari alpha 5 persen. Jadi dapat dinyatakan bahwa, model uji terbebas dari kasus heteroskedastisitas atau dapat dikatakan tidak ada heterokedastisitas.

Analisis regresi linier berganda digunakan untuk mengetahui besarnya pengaruh variabel kesadaran wajib pajak, kualitas pelayanan, pengetahuan perpajakan, sanksi perpajakan, sosialisasi perpajakan, sebagai variabel independen (variabel bebas) terhadap kepatuhan wajib pajak (Y) yang berfungsi sebagai variabel dependen (variabel terikat). Adapun rangkuman dari hasil uji regresi linier berganda dapat ditunjukkan pada Tabel 9 sebagai berikut. 
Tabel 9.

Hasil Uji Regresi Linier Berganda

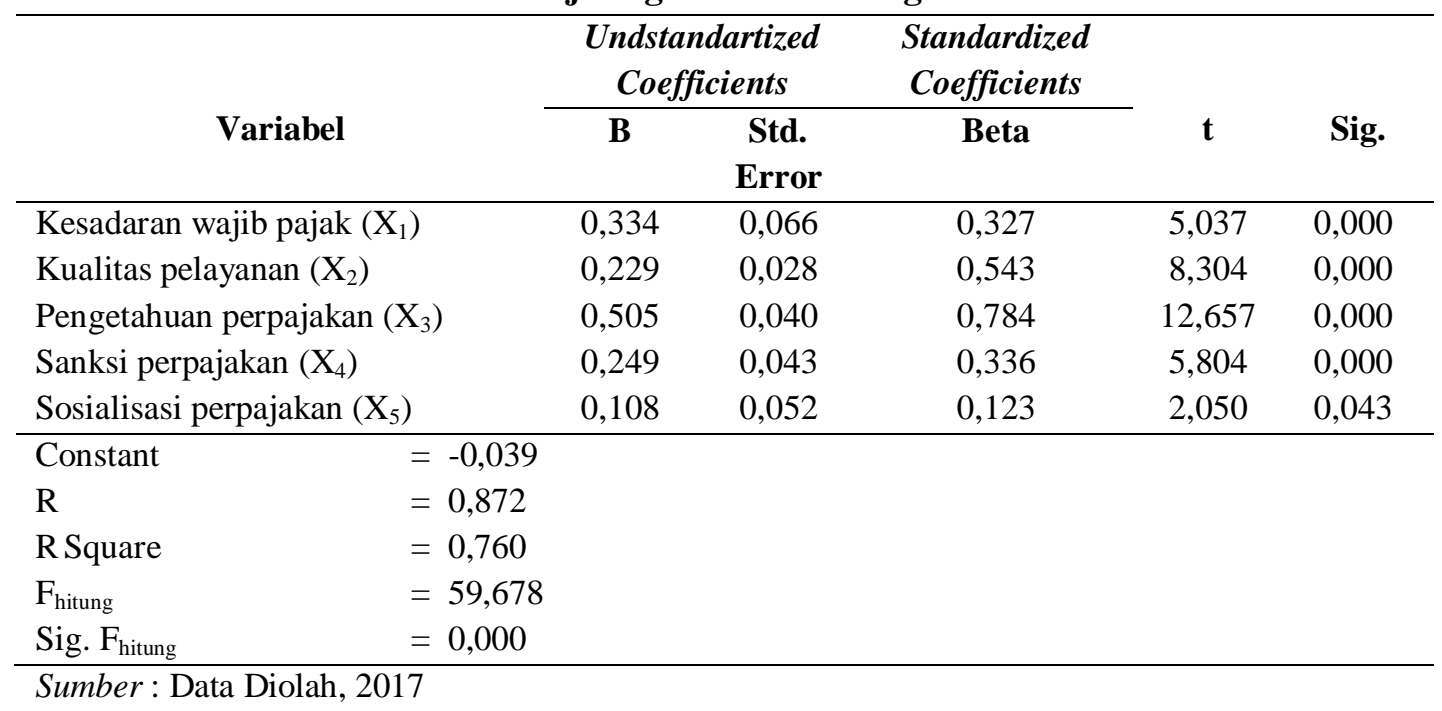

Berdasarkan Tabel 9 dapat diketahui bahwa, persamaan regresi yang dihasilkan adalah sebagai berikut.

$$
Y=-0,039+0,334 X_{1}+0,229 X_{2}+0,505 X_{3}+0,249 X_{4}+0,108 X_{5+} \varepsilon
$$

Berdasarkan hasil persamaan ini, dapat dijelaskan bahwa koefisien regresi kesadaran wajib pajak $\left(\beta_{1}\right)$ sebesar 0,334 berarti apabila kesadaran wajib pajak $\left(\mathrm{X}_{1}\right)$ dinaikkan satu satuan dan variabel lainya tidak berubah maka kepatuhan wajib pajak (Y) naik sebesar 0,334 satuan, artinya setiap peningkatan kesadaran wajib pajak dapat meningkatkan kepatuhan wajib pajak. Koefisien regresi kualitas pelayanan $\left(\beta_{2}\right)$ sebesar 0,229 berarti apabila kualitas pelayanan $\left(\mathrm{X}_{2}\right)$ dinaikkan satu satuan dan variabel lainya tidak berubah maka kepatuhan wajib pajak (Y) naik sebesar 0,229 satuan, artinya setiap peningkatan kualitas pelayanan dapat meningkatkan kepatuhan wajib pajak.

Koefisien regresi pemahaman perpajakan $\left(\beta_{3}\right)$ sebesar 0,505 berarti apabila pengetahuan perpajakan $\left(\mathrm{X}_{3}\right)$ dinaikkan satu satuan dan variabel lainya tidak berubah maka kepatuhan wajib pajak (Y) naik sebesar 0,505 satuan, artinya setiap 
peningkatan pengetahuan perpajakan dapat meningkatkan kepatuhan wajib pajak. Koefisien regresi sanksi perpajakan $\left(\beta_{4}\right)$ sebesar 0,249 berarti apabila sanksi perpajakan $\left(\mathrm{X}_{4}\right)$ dinaikkan satu satuan dan variabel lainya tidak berubah maka kepatuhan wajib pajak (Y) naik sebesar 0,249 satuan, artinya setiap peningkatan sanksi perpajakan dapat meningkatkan kepatuhan wajib pajak. Koefisien regresi sosialisasi perpajakan $\left(\beta_{5}\right)$ sebesar 0,108 berarti apabila sosialisasi perpajakan $\left(\mathrm{X}_{5}\right)$ dinaikkan satu satuan dan variabel lainya tidak berubah maka kepatuhan wajib pajak (Y) naik sebesar 0,108 satuan, artinya setiap peningkatan sosialisasi perpajakan dapat meningkatkan kepatuhan wajib pajak.

Uji koefisien determinasi dilakukan untuk mengetahui seberapa jauh kemampuan variabel bebas (independen) menerangkan variabel terikatnya (dependen), ini dapat dilihat dari nilai $\mathrm{R}^{2}$. Berdasarkan Tabel 4.10 nilai $\mathrm{R}^{2}$ sebesar 0,760, ini berarti sebesar 76 persen variabel kesadaran wajib pajak, kualitas pelayanan, pemahaman peraturan, sanksi perpajakan, sosialisasi perpajakan mempengaruhi kepatuhan wajib pajak, sedangkan sisanya sebesar 24 persen dipengaruhi oleh variabel lain yang tidak dimasukkan dalam penelitian.

Uji kelayakan model (uji F) bertujuan untuk menguji apakah semua variabel bebas berpengaruh terhadap variabel terikat dan untuk mengetahui model regresi yang digunakan dalam penelitian ini layak uji atau tidak. Berdasarkan Tabel 4.10 diperoleh nilai dari signifikansi 0,000 yang lebih kecil dari 0,05. Ini berarti bahwa ada pengaruh antara variabel variabel kesadaran wajib pajak, kualitas pelayanan, pemahaman peraturan, sanksi perpajakan, sosialisasi perpajakan secara simultan terhadap variabel kepatuhan WP. 
Berdasarkan hasil uji t dan nilai signifikasi pada variabel kesadaran wajib pajak $\left(\mathrm{X}_{1}\right)$ menunjukkan nilai sig lebih kecil dari 0,05 maka dapat disimpulkan bahwa, kesadaran wajib pajak berpengaruh positif dan signifikan terhadap kepatuhan wajib pajak (Y). Hasil penelitian memberikan makna bahwa semakin tinggi kesadaran wajib pajak maka wajib pajak semakin patuh, semakin rendah kesadaran wajib pajak maka wajib pajak semakin tidak patuh. Hasil ini mendukung penelitian yang dilakukan Yudha (2011) membuktikan bahwa kesadaran wajib pajak berpengaruh positif terhadap kepatuhan wajib pajak dalam membayar pajak Bea Balik Nama Kendaraan Bermotor (BBNKB) pada kantor bersama SAMSAT Denpasar. Penelitian Putri (2012) mengatakan bahwa faktor kesadaran perpajakan wajib pajak berpengaruh positif terhadap kepatuhan wajib pajak dalam membayar pajaknya. Hasil tersebut menunjukkan bahwa wajib pajak yang memiliki kesadaran wajib pajak akan lenih patuh dalam menunaikan kewajiban pajak kendaraan bermotornya.

Berdasarkan hasil uji t dan nilai signifikasi pada variabel kualitas pelayanan $\left(\mathrm{X}_{2}\right)$ menunjukkan nilai sig lebih kecil dari 0,05 maka dapat disimpulkan bahwa, kualitas pelayanan berpengaruh positif dan signifikan terhadap kepatuhan wajib pajak (Y). Hasil penelitian memberikan makna bahwa semakin tinggi kualitas pelayanan maka wajib pajak semakin patuh, semakin rendah kualitas pelayanan maka wajib pajak semakin tidak patuh. Hasil ini didukung oleh penelitian yang dilakukan oleh Andriana (2011) menunjukkan bahwa kualitas pelayanan berpengaruh positif terhadap kepatuhan wajib pajak memenuhi kewajiban pajak. 
Menurut Adi (2014) kualitas pelayanan berpengaruh positif pada kepatuhan wajib pajak dalam membayar pajak hotel.

Berdasarkan hasil uji $\mathrm{t}$ dan nilai signifikasi pada variabel pemahaman peraturan $\left(\mathrm{X}_{3}\right)$ menunjukkan nilai sig lebih kecil dari 0,05 maka dapat disimpulkan bahwa, kesadaran wajib pajak berpengaruh positif dan signifikan terhadap kepatuhan wajib pajak (Y). Hasil penelitian memberikan makna bahwa semakin tinggi pemahaman peraturan maka wajib pajak semakin patuh, semakin rendah pemahaman peraturan maka wajib pajak semakin tidak patuh. Hasil penelitian ini didukung oleh penelitian Pratiwi (2015) menunjukkan bahwa pemahaman peraturan perpajakan berpengaruh positif pada kepatuhan wajib pajak hotel di Kota Denpasar. Hasil Penelitian yang dilakukan oleh Winoto (2008) menunjukkan bahwa pengetahuan pajak berpengaruh signifikan terhadap kepatuhan wajib pajak.

Berdasarkan hasil uji t dan nilai signifikasi pada variabel sanksi perpajakan $\left(\mathrm{X}_{4}\right)$ menunjukkan nilai sig lebih kecil dari 0,05 maka dapat disimpulkan bahwa, sanksi perpajakan berpengaruh positif dan signifikan terhadap kepatuhan wajib pajak (Y). Hasil penelitian memberikan makna bahwa semakin tinggi sanksi perpajakan maka wajib pajak semakin patuh, semakin rendah sanksi perpajakan maka wajib pajak semakin tidak patuh. Hasil penelitian ini medukung penelitian yang dilakukan oleh Agus (2006) membuktikan melalui penelitiannya bahwa sanksi perpajakan berpengaruh positif terhadap kepatuhan wajib pajak orang pribadi di Kota Semarang. 
Berdasarkan hasil uji $\mathrm{t}$ dan nilai signifikasi pada variabel sosialisasi perpajakan $\left(\mathrm{X}_{5}\right)$ menunjukkan nilai sig lebih kecil dari 0,05 maka dapat disimpulkan bahwa, sosialisasi perpajakan berpengaruh positif dan signifikan terhadap kepatuhan wajib pajak (Y). Hasil penelitian memberikan makna bahwa semakin tinggi sosialisasi perpajakan maka wajib pajak semakin patuh, semakin kurang sosialisasi perpajakan maka wajib pajak semakin tidak patuh. Hasil penelitian ini mendukung penelitian yang dilakukan oleh Dharma (2014), menyimpulkan bahwa sosialisasi perpajakan berpengaruh signifikan terhadap Kepatuhan Wajib Pajak PKB dan BBNKB.

\section{SIMPULAN}

Berdasarkan hasil pembahasan yang telah diuraikan, maka simpulan yang diperoleh yaitu yang pertama, Kesadaran wajib pajak berpengaruh signifikan terhadap kepatuhan wajib pajak. Kedua, kualitas pelayanan berpengaruh signifikan terhadap kepatuhan wajib pajak. Ketiga, pemahaman peraturan berpengaruh signifikan terhadap kepatuhan wajib pajak. Keempat, sanksi perpajakan berpengaruh signifikan terhadap kepatuhan wajib pajak. Kelima, sosialisasi perpajakan berpengaruh signifikan terhadap kepatuhan wajib pajak.

Berdasarkan simpulan tersebut, maka saran yang dapat diberikan yaitu bagi peneliti selanjutnya diharapkan dapat secara lebih mendalam meneliti kepatuhan wajib pajak dalam membayar pajak kendaraan bermotor secara lebih spesifik agar mampu meningkatkan kepatuhan wajib pajak. Kemudian, bagi kantor SAMSAT agar dapat melakukan sosialisasi secara kontinyu kepada masyarakat mengenai perpajakan di setiap daerah di Kabupaten Gianyar. Hal ini untuk memberikan 
pemahaman dan meningkatkan kepatuhan wajib pajak sehingga sosialisasi diberikan dapat dipahami dengan baik. Sedangkan, bagi para wajib pajak orang agar lebih menyadari pentingnya pajak sebagai sumber pembiayaan Negara guna menyejahterakan rakyat, sehingga kepatuhan wajib pajak dapat lebih ditingkatkan.

\section{REFERENSI}

Adi Putra Sanjaya. 2014. Pengaruh Kualitas Pelayanan, Kewajiban Moral dan Sanksi Perpajakan Pada Kepatuhan Wajib Pajak Dalam Membayar Pajak Hotel. ISSN: 2302-8556. E-Jurnal Akuntansi Universitas Udayana 7.1 (2014): 207-222).

Agus Nugroho, Jatmiko. 2006. "Pengaruh Sikap Wajib Pajak pada Pelaksanaan Sanksi Denda, Pelayanan Fiskus dan Kesadaran Perpajakan terhadap Kepatuhan Wajib Pajak (Studi Empiris terhadap Wajib Pajak Orang Pribadi di Kota Semarang)". Thesis Magister Akuntansi Program Pascasarjana Universitas Diponegoro.

Andriana, Ateng. 2011. Analisis Atas Pengaruh Penerapan Self Assessment System Dan Kualitas Pelayanan Pajak Terhadap Kepatuhan Format Wajib Pajak di KPP Cicadas Kota Bandung. Skripsi Unikom. Bandung.

Chau, Leung. 2009. A Critical Review of Fischer Tax Compliance Model. Journal of Accounting and Taxation.

Chintya Dewi, A.A. Ari, Lely Aryani. 2013. Analisis Tingkat Kepatuhan Wajib Pajak Atas Pemenuhan Kewajiban Pajak Hotel dan Restoran di Kab. Badung Tahun 2011. ISSN: 2302-8556. E-Jurnal Akuntansi Universitas Udayana 4.1 (2013): 110-127

Cindy Jotopurnomo dan Yenni Mangoting. 2013. Pengaruh Kesadaran Wajib Pajak, Kualitas Pelayanan Fiskus, Sanksi Perpajakan, Lingkungan Wajib Pajak Berada terhadap Kepatuhan Wajib Pajak Orang Pribadi di Surabaya. Tax and Accounting Review, Volume 1 (2009).

Davis, J.S., Hecht, G. \& Perkins, J.D., 2003. Social Behaviors, Enforcement, and Tax Compliance Dynamics. The Accounting Review, 78(1), pp.39-69.

Dewinta, Rinta Mulia dan Syafruddin. 2012. Pengaruh Persepsi Pelaksanakan Sensus Pajak Nasional dan Kesadaran Perpajakan terhadap Kepatuhan Wajib Pajak di Lingkungan Kantor Wilayah Direktorat Jenderal Pajak Daerah Istimewa Yogyakarta. Diponegoro journal of accounting. Vol. 1. No. 2. h:1-9. 
Dharma, Gede Pani Esa dan Suardana. 2014. Pengaruh Kesadaran Wajib Pajak, Sosialisasi Perpajakan, Kualitas Pelayanan Pada Kepatuhan Wajib Pajak. ISSN: 2302-8556. E-Jurnal Akuntansi Universitas Udayana 6.1 (2014): 340-353.

Gilbert, G. Ronald, Veloutsou Clepatra, Goode, Mark M.H. and Moutinho L. 2004. Measuring Customer Satisfaction in the Fast Food Industry: a Cross National Approch. The Journal of Service Marketing, 18(5): p:371-383.

Gerald, Chau and Patrick Leung. 2009. A Critical Review of Fischer Tax Compliance Model (A Research Syntesis). Journal of Accounting and Taxation. 1(2): h:34-40.

Hammer.H., S.C. Jagers dan K. Nordblom. 2005. Tax Evasion and The Importance of Trust. Working Paper, Goteborg University.

Hardiningsih, Pancawati \& Nila Yulianawati. 2011. Faktor-Faktor yang Mempengaruhi Kemauan Membayar Pajak. Dinamika Keuangan dan Perbankan. 3(1): h:126-142.

Januarta, Agnes Dian. 2011. Pengaruh Kewajiban Moral, Kualitas Pelayanan dan Sanksi Perpajakan pada Kepatuhan Wajib Pajak dalam Membayar Pajak Kendaraan Bermotor (PKB) di Kantor Bersama SAMSAT Tabanan. Skripsi Sarjana Fakultas Ekonomi Universitas Udayana.

James \& Nobes. 1997. The Economics of Taxation, Prnciple, Policy and Practice, Europe: Prentice Hall.

Kurniawan. 2006. Pengaruh Sosialisasi Pajak Bumi dan Bangunan Terhadap Kepatuhan Wajib Pajak di Kabupaten Kudus. Jurnal Perpajakan. Kudus: Universitas Negeri Semarang

Mardiasmo. 2013, Perpajakan. Edisi Revisi. Yogyakarta: Andi.

Niemirowski, Pauline, Steve Baldwin and Alexander J Wearing. 2003. Tax Related Behaviours, Beliefs, Attitudes And Values And Taxpayer Compliance In Australia. Journal Of Australian Taxation.

Pani Esa Dharma dan Alit Suardana. 2014. Pengaruh Kesadaran Wajib Pajak, Sosialisasi Perpajakan, Kualitas Pelayanan Pada Kepatuhan Wajib Pajak Kendaraan Bermotor. ISSN: 2302-8556. E-Jurnal Akuntansi Universitas Udayana 6.1 (2014): 340-353.

Putri, Amanda R. Siswanto dan Jati. 2012. Faktor-Faktor Yang Mempengaruhi Kepatuhan Wajib Pajak Dalam Membayar Pajak Kendaraan Bermotor Di Denpasar. E-Jurnal Universitas Udayana. 
Pratiwi, Putu Surya. 2015. Pengaruh Pemahaman Peraturan, Administrasi, dan Sanksi Perpajakan Pada Kepatuhan Wajib Pajak Hotel di Kota Denpasar. Skripsi. Sarjana Fakultas Ekonomi dan Bisnis Universitas Udayana.

Rajif, Mohamad. 2012. Pengaruh Pemahaman, Kualitas Pelayanan dan Ketegasan Sanksi Perpajakan terhadap Kepatuhan Pajak UKM di Cirebon. E-journal Universitas Gunadarma.

Sulistianingrum, 2009. Kualitas Pelayanan Administrasi dan Sosialisasi Perpajakan terhadap Tingkat Kepatuhan Wajib Pajak (Studi Kasus pada KPP Pratama Jakarta Setiabudi Satu). Skripsi. Fakultas Ekonomi Universitas Pembangunan Nasional "Veteran" Jakarta.

Sugi Astana dan Lely Aryani. 2017. Pengaruh Penerapan Sistem Administrasi Perpajakan Modern dan Kesadaran Wajib Pajak pada Kepatuhan Wajib Pajak. ISSN: 2302-8556. E-Jurnal Akuntansi Universitas Udayana Vol.18.1. Januari (2017): 818-846

Sugiyono. 2016. Metode Penelitian Bisnis. Bandung: CV. Alfabeta.

Susilawati, Ketut Evi dan Budiartha.2013. Pengaruh Kesadaran Wajib Pajak, Pengetahuan Pajak, Sanksi Perpajakan Dan Akuntabilitas Pelayanan Publik Pada Kepatuhan Wajib Pajak Kendaraan Bermotor. ISSN: 23028556. E-Jurnal Akuntansi Universitas Udayana 4.2 (2013): 345-357).

Undang-Undang Nomor 28 Tahun 2009 Tentang Pajak Daerah dan Retribusi Daerah. Jakarta.

Wahyu Santoso. 2008. Analisis Risiko Ketidakpatuhan Wajib Pajak Sebagai Dasar Peningkatan Kepatuhan Wajib Pajak (Penelitian terhadap Wajib Pajak Badan di Indonesia). Jurnal Keuangan Publik, 5 (1): h:85-138.

Winerungan, Lidya Oktaviane. 2013. "Sosialisasi Perpajakan, Pelayanan Fiskus dan Sanksi Perpajakan terhadap Kepatuhan WPOP di KPP Manado dan KPP Bitung”. Jurnal EMBA. Vol 1, No.3, 960-970.

Winoto, Banu. 2008. Peranan Pengetahuan Pajak Pada Kepatuhan Wajib Pajak. Jurnal Akuntansi dan Keuangan, 7(2): h: 196-208.

Yadnyana dan Sudiksa. 2011. Pengaruh Peraturan Pajak Serta Sikap Wajib Pajak Pada Kepatuhan Wajib Pajak Koperasi di Kota Denpasar. Buletin Studi Ekonomi, 17(2):h:197-206. Denpasar: Fakultas Ekonomi Universitas Udayana).

Yudha, I Gusti Agung Gede. 2011. Pengaruh Kesadaran Wajb Pajak, Kewajiban Moral Dan Biaya Kepatuhan Terhadap Kepatuhan Wajib Pajak Dalam 
Membayar Pajak Bea Balik Nama Kendaraan Bermotor (BBNKB) Pada Kantor Bersama SAMSAT Denpasar. Skripsi Sarjana Fakultas Ekonomi Universitas Udayana.

Yulayca, Ardian Rahmawati. 2013. Analisis Modernisasi Sistem Administrasi Perpajakan dan Pengetahuan Perpajakan terhadap Kepatuhan Pengusaha Kena Pajak. Skripsi. Sarjana Jurusan Akuntansi pada Fakultas Ekonomi dan Bisnis Universitas Muhammadiyah Surakarta, Surakarta. 